\title{
Effects of cowdung and potassium on growth and yield of Kohlrabi
}

\author{
J. Sultana, M. A. Siddique and M. H. A. Rashid \\ Department of Horticulture, Bangladesh Agricultural University, Mymensingh- 2202, Bangladesh \\ E-mail: mharashids@yahoo.com
}

\begin{abstract}
An experiment was carried out at the Horticulture Farm of the Bangladesh Agricultural University, Mymensingh during the period from November 2010 to January 2011 to study the effects of cowdung and potassium on growth and yield of Kohlrabi. The experiment consisted of three levels of cowdung ( 0,20 and $40 \mathrm{t} / \mathrm{ha}$ ) and four levels of potassium ( 0 , $20,50,80 \mathrm{~kg} / \mathrm{ha}$ ). The experiment was laid out in randomized complete block design with three replications. All the parameters were significantly influenced by application of cowdung and potassium. The highest plant height (44.65 $\mathrm{cm})$, number of leaves per plant (12.11), length of largest leaf $(37.54 \mathrm{~cm})$, and breadth of largest leaf $(18.66 \mathrm{~cm})$ were obtained from the highest dose of cowdung and potassium applied (40 t cowdung $+80 \mathrm{~kg} \mathrm{~K} / \mathrm{ha}$ ) while the lowest plant height $(33.64 \mathrm{~cm})$, number of leaves $(9.01)$, length of largest leaf $(27.94 \mathrm{~cm})$, and breadth of largest leaf $(11.00$ $\mathrm{cm})$ were obtained from control treatment combination. The highest fresh weight of leaves $(49.33 \mathrm{~g})$, fresh weight of knob $(328.66 \mathrm{~g})$ and fresh weight of roots $(66.55 \mathrm{~g})$ per plant were also recorded under the treatment combination of $40 \mathrm{t}$ cowdung $+80 \mathrm{~kg} \mathrm{~K} / \mathrm{ha}$, while the lowest fresh weight of leaves $(22.11 \mathrm{~g})$, fresh weight of knob (136.00 g) and fresh weight of roots $(23.33 \mathrm{~g})$ were obtained from control treatment combination. Similarly, the dry weight of leaves (19.34\%), knob (15.19\%) and roots (32.75\%) were highest under the same treatment combination of $40 \mathrm{t}$ cowdung + $80 \mathrm{~kg} \mathrm{~K} / \mathrm{ha}$ and the lowest dry weight of leaves (11.71\%), dry weight of knob (7.38\%) and dry weight of roots $(15.29 \%)$ were obtained from control treatment combination $\mathrm{C}_{0} \mathrm{~K}_{0}$. The marketable yields of $\mathrm{knob}$ per plot $(7.86 \mathrm{~kg})$ and per hectare (39.58 tons) were also the highest under the treatment combination $40 \mathrm{t}$ cowdung/ha and $80 \mathrm{~kg}$ potassium per hectare.
\end{abstract}

Keywords: Kohlrabi, Cowdung, Potassium, Growth, Yield

\section{Introduction}

Kohlrabi (Brassica oleracea var. gongylodes), a member of the cole crops, is also known as Knolkhol and Ol-kapi. It belongs to the family Cruciferae and is of north-European origin. The stem, which is the edible part is generally enlarged immediately above ground (Nieuwhof, 1996). Production of Kohlrabi depends on many factors such as quality of seed, variety, plant spacing, fertilizer and proper management practices. The production of Kohlrabi has not been extended much beyond the agricultural farms in Bangladesh (BBS, 2009). Kohlrabi responds greatly to major essential nutrients, like, N, P, K and organic fertilizer in respect of growth and yield. In 2009-2010, Bangladesh produces 35 thousand tones of Kohlrabi per year from 7.29 thousand hectares of land with an average yield of $4.80 \mathrm{t} \mathrm{ha}^{-1}$ which is very low against the potential yield (BBS, 2010). Potassium is considered essential in photosynthesis, sugar translocation, nitrogen metabolism, enzyme activation, stomatal opening, water relation and growth of meristematic tissue. It acts as chemical traffic policeman, root booster, stalk strengtheners, protein builder and breathing regulator and retards diseases. But potassium is not fully effective without its co-efficients such as $\mathrm{N}$ and $\mathrm{P}$ (Chandra, 1989). Deficiency of potassium may hamper various physiological processes such as, respiration, photosynthesis, chlorophyll development, and may reduce water content of leaves which is directly related to plant growth and yield. The cost of inorganic fertilizers is very high and sometimes it is not available in the market. Consequently, the farmers fail to apply inorganic fertilizer to the crop field in the optimum dose. On the other hand, the organic fertilizer is easily available to the farmers, and its cost is relatively low than the inorganic fertilizers. The crop production cost is more or less similar to organic and inorganic fertilizer (Haque, 2000). The readily available organic sources of nutrients should, therefore, be used to maximize the economic return. Therefore, the present study was undertaken to study the effect of cowdung and potassium on growth and yield for obtaining high economic return of Kohlrabi. 


\section{Materials and Methods}

The present study was carried out at the Horticultural Farm of the Bangladesh Agricultural University, Mymensingh during the period from October 2010 to January 2011. The soil of the experimental plot was silty loam in texture and medium high in nature belonging to the Old Brahmaputra Floodplain Alluvium under the Agro-Ecological Zone 9 (UNDP and FAO, 1988). The variety of Kohlrabi selected for the experiment was Winter queen F-1. It is a hybrid variety and originated from Japan. Seeds were sown on 12 October 2010. The experiment consisted of 3 levels of cowdung manure (0,20 and $\left.40 \mathrm{t} \mathrm{ha}^{-1}\right)$ and 4 levels of potassium $\left(0,20,50,80 \mathrm{~kg} \mathrm{~K}^{-1}\right)$. The two factor experiment comprised 12 treatment combinations, and was laid out in randomized complete block design with three replications. The total number of plots was 36 . The size of each unit plot was $1.6 \mathrm{~m} \times 1.2 \mathrm{~m}$. The crop was fertilized with urea, TSP, Borax @ of 200, 150 and 10 kg per hectare, respectively (Haque, 1985). Entire amount of cowdung and TSP, half of MoP and one third of urea were applied in respective plots as per treatment during the final land preparation. The rest of urea and MoP were applied in 3 equal installments. Data on plant height, number of leaves, length of largest leaf and breadth of largest leaf were collected 20 days after transplanting (DAT). All other parameters were recorded during harvest and after harvest. The collected data were analyzed statistically and analysis of variance was done with the help of MSTAT computer programme. The mean differences among the treatments were tested with least significant difference (LSD) at 5 and 1\% levels of probability (Gomez and Gomez, 1984).

\section{Results and Discussion}

\section{Effects of cowdung}

Cowdung significantly influenced the plant height, number of leaves, number of lateral roots per plants, fresh weight of leaves and knob, dry weight of leaves and knob per plant and marketable yield per plot and per hectare of kohlrabi. The highest plant height $(40.38 \mathrm{~cm})$ was obtained from the $\mathrm{C}_{2}(40 \mathrm{t}$ cowdung $\left.\mathrm{ha}^{-1}\right)$ treatment while the lowest plant height $(37.05 \mathrm{~cm})$ was obtained from $\mathrm{C}_{0}\left(0 \mathrm{t}\right.$ cowdung ha $\left.{ }^{-1}\right)$ treatment (Table 1). Cowdung showed highly significant effect on the number of leaves per plant. The maximum number of leaves per plant (10.59) was obtained from $\mathrm{C}_{2}\left(40 \mathrm{t}_{\text {cowdung }} \mathrm{ha}^{-1}\right.$ ) treatment while the minimum number of leaves (9.55) was found from the treatment of $\mathrm{C}_{0}\left(0 \mathrm{t}\right.$ cowdung ha $\left.{ }^{-1}\right)$ at harvest (Table 1). Similar results were also observed by Subhan (1988). He observed that application of organic manure increased the average number of leaves per plant. The number of lateral roots per plant showed significant response to different doses of cowdung. Cowdung at $40 \mathrm{t} \mathrm{ha}^{-1}$ gave the highest number of lateral roots per plant (15.60) while the minimum (11.71) was recorded with control $\left(0 \mathrm{t}\right.$ cowdung ha ${ }^{-1}$ treatment (Table 1). From the above results it was noted that cowdung kept the soil loose, porous, increased moisture content, microbial activities and provided proper aeration and as a result plant nutrients became more available for better growth and development of roots which ultimately increased the number of lateral roots (Azad, 2000). The maximum fresh weight of leaves (44.08 g) per plant was obtained when the plants received $\mathrm{C}_{2}$ (40 $\mathrm{t}_{\text {cowdung }} \mathrm{ha}^{-1}$ ) treatment while the minimum fresh weight (33.31 g) was found from the treatment $\mathrm{K}_{0}$ (control) (Table 1). The maximum fresh weight of knob per plant $(258.99 \mathrm{~g})$ was obtained when the plants received $\mathrm{C}_{2}\left(40 \mathrm{t} \mathrm{cowdung} \mathrm{ha}^{-1}\right)$ treatment while the minimum fresh weight $(171.16 \mathrm{~g})$ was recorded from $\mathrm{C}_{0}$ (control). The highest dry weight of leaves (15.68\%) was recorded from the $\mathrm{C}_{2}\left(40 \mathrm{t}_{\text {cowdung }} \mathrm{ha}^{-1}\right)$ treatment while the minimum dry weight $(12.62 \%)$ was found from control $\left(0 \mathrm{t}\right.$ cowdung ha $\left.{ }^{-1}\right)$ treatment at harvest The highest dry weight of knob (13.13\%) was recorded with the $C_{2}\left(40 \mathrm{t}_{\text {cowdung }} \mathrm{ha}^{-1}\right)$ treatment and the minimum dry weight of knob (8.22\%) was found from control $\left(0 \mathrm{t}\right.$ cowdung ha $\left.{ }^{-1}\right)$ treatment. The highest marketable yield per plot $(6.52 \mathrm{~kg})$ and per hectare $\left(34.14 \mathrm{t} \mathrm{ha}^{-1}\right)$ were found from $\mathrm{C}_{2}\left(40 \mathrm{t}_{\text {cowdung ha }}{ }^{-1}\right)$ treatment while the minimum marketable yield per plot $(4.60 \mathrm{~kg})$ and per hectare $\left(24.00 \mathrm{t} \mathrm{ha}^{-1}\right)$ were obtained from control (0 t cowdung ha $\left.{ }^{-1}\right)$ treatment (Table 1 and Fig. 1). 
Table 1. Main effect of cowdung and potassium on the growth and yield components of Kohlrabi

\begin{tabular}{|c|c|c|c|c|c|c|c|c|}
\hline Treatments & $\begin{array}{l}\text { Plant } \\
\text { height } \\
(\mathrm{cm})\end{array}$ & $\begin{array}{c}\text { No. of } \\
\text { leaves/pl } \\
\text { ant }\end{array}$ & $\begin{array}{c}\text { No. of lateral } \\
\text { roots / } \\
\text { plant }\end{array}$ & $\begin{array}{c}\text { Fresh wt. of } \\
\text { leaves } \\
\text { /plant (g) }\end{array}$ & $\begin{array}{c}\text { Fresh wt. of } \\
\text { knob/ } \\
\text { plant }(\mathrm{g})\end{array}$ & $\begin{array}{c}\text { Dry wt. of } \\
\text { leaves/ } \\
\text { plant (\%) }\end{array}$ & $\begin{array}{l}\text { Dry wt. of } \\
\text { knob/ } \\
\text { plant (\%) }\end{array}$ & $\begin{array}{c}\text { Marketable } \\
\text { yield/plot } \\
(\mathrm{kg})\end{array}$ \\
\hline $\mathrm{C}_{0}$ & 37.05 & 9.55 & 11.71 & 33.31 & 171.16 & 12.62 & 8.22 & 4.60 \\
\hline $\mathrm{C}_{1}$ & 38.87 & 9.89 & 13.38 & 37.73 & 209.14 & 12.97 & 9.68 & 5.36 \\
\hline $\mathrm{C}_{2}$ & 40.38 & 10.59 & 15.60 & 44.08 & 258.99 & 15.68 & 13.13 & 6.52 \\
\hline $\operatorname{LSD}_{(0.05)}$ & 0.545 & 0.340 & 0.356 & 0.551 & 5.872 & 0.496 & 0.519 & 0.116 \\
\hline $\operatorname{LSD}_{(0.01)}$ & 0.764 & 0.477 & 0.499 & 0.773 & 8.232 & 0.696 & 0.727 & 0.163 \\
\hline $\mathrm{K}_{0}$ & 34.74 & 9.59 & 11.44 & 31.44 & 179.70 & 12.80 & 9.46 & 4.63 \\
\hline $\mathrm{K}_{1}$ & 38.94 & 9.74 & 12.65 & 36.43 & 207.40 & 13.30 & 10.75 & 5.23 \\
\hline $\mathrm{K}_{2}$ & 39.12 & 9.79 & 13.62 & 40.60 & 206.29 & 13.50 & 9.62 & 5.92 \\
\hline $\mathrm{K}_{3}$ & 42.26 & 10.92 & 16.55 & 45.02 & 259.00 & 15.43 & 11.55 & 6.18 \\
\hline $\operatorname{LSD}_{(0.05)}$ & 0.653 & 0.407 & 0.427 & 0.661 & 7.039 & 0.595 & 0.622 & 0.139 \\
\hline $\operatorname{LSD}_{(0.01)}$ & 0.938 & 0.585 & 0.613 & 0.949 & 10.113 & 0.854 & 0.893 & 0.200 \\
\hline $\begin{array}{l}\text { Level of } \\
\text { significance }\end{array}$ & ** & $\star *$ & $\star *$ & ** & ** & ** & ** & ** \\
\hline
\end{tabular}

(** = Significant at $1 \%$ level of probability, DAT= Days after transplanting, $\mathrm{C}_{0}=0 \mathrm{t}$ cowdung/ha, $\mathrm{C}_{1}=20 \mathrm{t} \mathrm{cowdung} / \mathrm{ha}$, $\mathrm{C}_{2}=40 \mathrm{t}$ cowdung $/ \mathrm{ha}, \mathrm{K}_{0}=0 \mathrm{~kg}$ potash $/ \mathrm{ha}, \mathrm{K}_{1}=20 \mathrm{~kg}$ potash $/ \mathrm{ha}, \mathrm{K}_{2}=50 \mathrm{~kg}$ potash $/ \mathrm{ha}, \mathrm{K}_{3}=80 \mathrm{~kg}$ potash $/ \mathrm{ha}$ )

\section{Effects of potassium}

Potassium showed significant effect on plant height, number of leaves, number of lateral roots per plant, fresh weight of leaves and knobs per plant, dry weight of leaves and knob per plant, marketable yield per plot and per hectare. The longest plant height $(42.26 \mathrm{~cm})$ at harvest was recorded from $\mathrm{K}_{3}\left(80 \mathrm{~kg} \mathrm{~K} \mathrm{ha}^{-1}\right)$ treatment while the shortest plant height $(34.74 \mathrm{~cm})$ was observed from $\mathrm{K}_{0}\left(0 \mathrm{~kg} \mathrm{~K} \mathrm{ha}^{-1}\right)$ (Table 1). The plant height increased with the increased doses of $\mathrm{K}$ fertilizer. This result is partially supported by Farooque and Mondal (1987). The maximum number of leaves per plant (10.92) was found from the $K_{3}$ $\left(80 \mathrm{~kg} \mathrm{~K} \mathrm{ha}^{-1}\right)$ treatment while the minimum (9.59) was found from control $\left(\mathrm{K}_{0}\right)$ treatment (Table 1). The maximum number of lateral roots (16.55) per plant was found from $\mathrm{K}_{3}\left(80 \mathrm{~kg} \mathrm{~K} \mathrm{ha}^{-1}\right)$ treatment while the minimum number of lateral roots (11.44) was recorded from $\mathrm{K}_{0}$ (control) (Table 1). The maximum fresh weight of leaves per plant $(43.71 \mathrm{~g})$ was found from the $\mathrm{K}_{3}\left(80 \mathrm{~kg} \mathrm{~K} \mathrm{ha}^{-1}\right)$ treatment and the minimum (3.24g) was found from control $\left(\mathrm{K}_{0}\right)$ treatment (Table 1). The present results are in full agreement with the report of Lawande et al. (1988). The maximum fresh weight of knob $(259.00 \mathrm{~g})$ was found from the $\mathrm{K}_{3}(80$ $\mathrm{kg} \mathrm{K} \mathrm{ha}^{-1}$ ) treatment while the minimum $(179.70 \mathrm{~g})$ was found from control $\left(\mathrm{K}_{0}\right)$ treatment (Table 1$)$. This result is in conformity with that of Lawande et al. (1988). The maximum dry weight of leaves (15.43\%) was recorded from the $\mathrm{K}_{3}\left(80 \mathrm{~kg} \mathrm{~K}\right.$ ha $\left.^{-1}\right)$ while the minimum dry weight of leaves $(12.80 \%)$ was found from $\mathrm{K}_{0}$ (control) treatment (Table 1). The maximum dry weight of knob (11.55\%) was recorded from the $\mathrm{K}_{3}(80$ $\mathrm{kg} \mathrm{K} \mathrm{ha}^{-1}$ ) while the minimum dry weight of knob (9.46\%) was found from $\mathrm{K}_{0}$ (control) treatment (Table 1$)$. Fischer (1992) found similar results in kohlrabi. The maximum marketable yield per plot $(6.18 \mathrm{~kg})$ was observed from the $\mathrm{K}_{3}\left(80 \mathrm{~kg} \mathrm{~K} \mathrm{ha}^{-1}\right)$ treatment while the minimum marketable yield per plot $(4.63 \mathrm{~kg})$ was found from $\mathrm{K}_{0}$ (control) treatment (Table 1). Gianquinto and Borin (1995) reported that marketable yield were greatest when kohlrabi received medium and high level NPK fertilizers. It might be due to the synergistic relation of nutrient elements for better uptake by plants. The maximum marketable yield per hectare $(31.77 \mathrm{t})$ was observed from the $\mathrm{K}_{3}\left(80 \mathrm{~kg} \mathrm{~K} \mathrm{ha}^{-1}\right)$ treatment while the minimum marketable yield per hectare (25.82 t) was found from $\mathrm{K}_{0}$ (control) treatment (Fig. 2). 


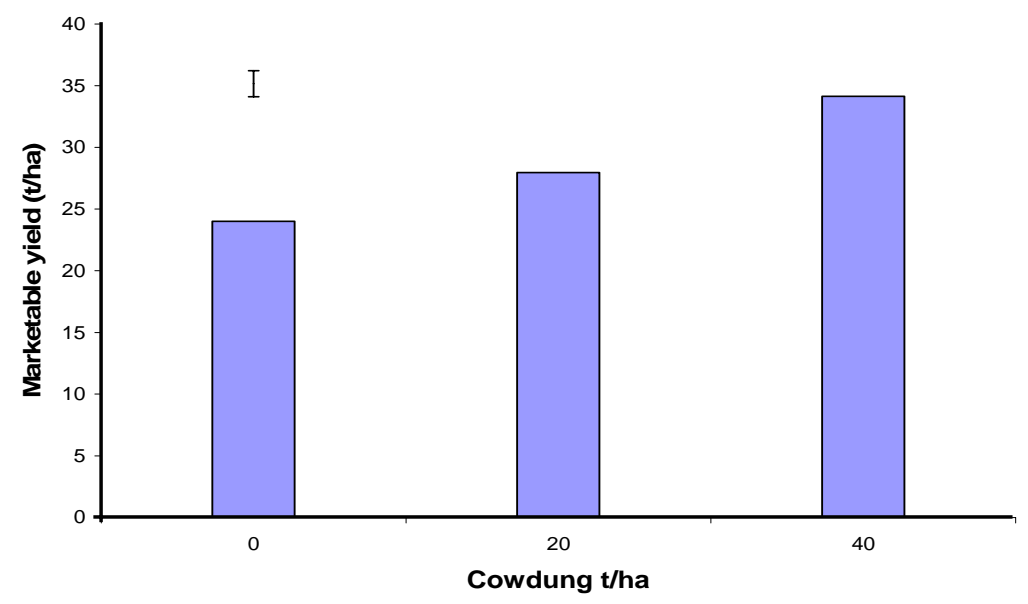

Fig. 1. Main effect of cowdung on marketable yield of Kohlrabi. Vertical bar represents LSD at $1 \%$ level of probability

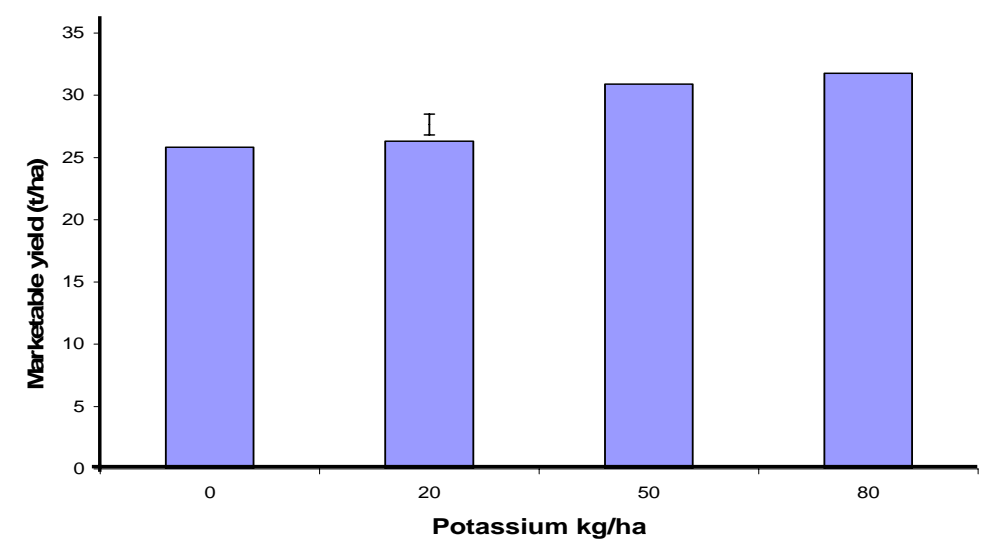

Fig. 2. Main effect of potassium on marketable yield of Kohlrabi. Vertical bar represents LSD at $1 \%$ level of probability

\section{Combined effects of cowdung and potassium}

The combined effect of cowdung and potassium was statistically significant on plant height, number of leaves, number of lateral roots per plant, fresh weight of leaves and knobs per plant, dry weight of leaves and knob per plant, marketable yield per plot and per hectare. The longest plant height $(44.65 \mathrm{~cm})$ was recorded from the treatment combination of $\mathrm{C}_{2} \mathrm{~K}_{3}\left(40 \mathrm{t} \mathrm{cowdung} \mathrm{ha}^{-1}\right.$ and $\left.80 \mathrm{~kg} \mathrm{~K}^{-1}\right)$ while the shortest plant height $(33.64 \mathrm{~cm})$ was found in the treatment combination of $\mathrm{C}_{0} \mathrm{~K}_{0}\left(0 \mathrm{t}\right.$ cowdung ha ${ }^{-1}$ and $\left.0 \mathrm{~kg} \mathrm{~K} \mathrm{ha}^{-1}\right)$ (Table 2). Azad (2000) found that combination of organic manures and inorganic fertilizers gave the highest plant height. The present findings also partially support the results of Busayong (1996) and Roe (1998). The maximum number of leaves (12.11) recorded from the treatment combination of $\mathrm{C}_{2} \mathrm{~K}_{3}(40 \mathrm{t}$ cowdung/ha and $\left.80 \mathrm{~kg} \mathrm{~K} \mathrm{ha}^{-1}\right)$ and the minimum (9.01) was found in the treatment combination of $\mathrm{C}_{0} \mathrm{~K}_{0}(0$ $\mathrm{t}$ cowdung ha ${ }^{-1}$ and $0 \mathrm{~kg} \mathrm{~K} \mathrm{ha}^{-1}$ ) (Table 2). Number of leaves per plant increased with combined application of cowdung and potash which is in agreement with that of Kabir (1998). The highest number of lateral roots (20.18) was recorded when plants were produced with $\mathrm{C}_{2} \mathrm{~K}_{3}$ (40 t cowdung ha- and $80 \mathrm{~kg}$ $\mathrm{K} \mathrm{ha}^{-1}$ ) treatment combination while the lowest number of lateral roots (9.21) was obtained from $\mathrm{C}_{0} \mathrm{~K}_{0}$ (control) (Table 2). The maximum fresh weight of leaves per plant $(49.33 \mathrm{~g})$ was obtained from the treatment combination of $\mathrm{C}_{2} \mathrm{~K}_{3}$ (40 t cowdung ha ${ }^{-1}$ and $\left.80 \mathrm{~kg} \mathrm{Kha}^{-1}\right)$ at harvest (Table 2) while the 
minimum fresh weight of leaves per plant $(22.11 \mathrm{~g})$ was found with the treatment combination of $\mathrm{C}_{0} \mathrm{~K}_{0}(0 \mathrm{t}$ cowdung ha ${ }^{-1}$ and $0 \mathrm{~kg} \mathrm{~K} \mathrm{ha}^{-1}$ ) (Table 2). The maximum fresh weight of knob (328.66 g) was obtained from the treatment combination of $\mathrm{C}_{2} \mathrm{~K}_{3}$ (40 t cowdung ha- ${ }^{-1}$ and $80 \mathrm{~kg} \mathrm{~K}^{-1}$ ) at harvest while the minimum fresh weight of knob $(136.00 \mathrm{~g})$ was found with the treatment combination of $\mathrm{C}_{0} \mathrm{~K}_{0}(0 \mathrm{t}$ cowdung $\mathrm{ha}^{-1}$ and $\left.0 \mathrm{~kg} \mathrm{~K} \mathrm{ha}^{-1}\right)$. The maximum dry weight of leaves per plant (19.34\%) was obtained from the treatment combination of $\mathrm{C}_{2} \mathrm{~K}_{3}$ (40 t cowdung ha-1 and $80 \mathrm{~kg} \mathrm{~K} \mathrm{ha}^{-1}$ ) while the lowest dry weight of leaves (11.71\%) was recorded from control treatment $\left(\mathrm{C}_{0} \mathrm{~K}_{0}\right)$ (Table 2). The maximum dry weight of knob (15.19\%) was obtained from the treatment combination of $\mathrm{C}_{2} \mathrm{~K}_{3}$ (40 t cowdung ha ${ }^{-1}$ and $80 \mathrm{~kg} \mathrm{~K} \mathrm{ha}^{-1}$ ) while control the lowest dry weight of knob (7.38\%) was recorded from the control treatment $\left(\mathrm{C}_{0} \mathrm{~K}_{0}\right)(\mathrm{Table}$ 2). The maximum marketable yield $(7.86 \mathrm{~kg})$ per plot was recorded from the treatment combination of $\mathrm{C}_{2} \mathrm{~K}_{3}\left(40 \mathrm{t}\right.$ cowdung ha ${ }^{-1}$ and $\left.80 \mathrm{~kg} \mathrm{~K} \mathrm{ha}^{-1}\right)$ while the minimum $(3.90 \mathrm{~kg}$ ) yield was obtained from the treatment combination of $\mathrm{C}_{0} \mathrm{~K}_{0}$ (control) (Table 2). The maximum marketable yield (39.58 $\mathrm{t}$ ) per hectare was recorded from the treatment combination of $\mathrm{C}_{2} \mathrm{~K}_{3}\left(40 \mathrm{t}\right.$ cowdung ha ${ }^{-1}$ and $\left.80 \mathrm{~kg} \mathrm{~K} \mathrm{ha}^{-1}\right)$ while the minimum marketable yield per hectare $(20.51 \mathrm{t})$ was obtained from the treatment combination of $\mathrm{C}_{0} \mathrm{~K}_{0}$ (control) (Table 2).

Table 2. Combined effects of cowdung and potassium on the growth and yield components of Kohlrabi

\begin{tabular}{|c|c|c|c|c|c|c|c|c|c|}
\hline $\begin{array}{l}\text { Treatment } \\
\text { combinations }\end{array}$ & $\begin{array}{l}\text { Plant } \\
\text { height } \\
(\mathrm{cm}) \\
\end{array}$ & $\begin{array}{l}\text { No. of } \\
\text { leaves/ } \\
\text { plant }\end{array}$ & $\begin{array}{c}\text { No. of } \\
\text { lateral } \\
\text { roots /plant }\end{array}$ & $\begin{array}{l}\text { Fresh wt. } \\
\text { of leaves/ } \\
\text { plant (g) }\end{array}$ & $\begin{array}{l}\text { Fresh wt. } \\
\text { of knob/ } \\
\text { plant (g) }\end{array}$ & $\begin{array}{c}\text { Dry wt. of } \\
\text { leaves/pl } \\
\text { ant (\%) } \\
\end{array}$ & $\begin{array}{c}\text { Dry wt. of } \\
\text { knob/plan } \\
t(\%)\end{array}$ & $\begin{array}{c}\text { Marketable } \\
\text { yield/plot } \\
(\mathrm{kg})\end{array}$ & $\begin{array}{c}\text { Marketable } \\
\text { yield } \\
\text { (t/ha) } \\
\end{array}$ \\
\hline $\mathrm{C}_{0} \mathrm{~K}_{0}$ & 33.64 & 9.01 & 9.21 & 136.00 & 15.76 & 7.38 & 15.29 & 3.90 & 20.51 \\
\hline $\mathrm{C}_{0} \mathrm{~K}_{1}$ & 36.96 & 9.52 & 10.90 & 195.55 & 18.36 & 8.30 & 16.30 & 4.70 & 24.48 \\
\hline $\mathrm{C}_{0} \mathrm{~K}_{2}$ & 38.00 & 9.33 & 13.11 & 170.00 & 17.69 & 8.11 & 16.33 & 4.80 & 25.00 \\
\hline $\mathrm{C}_{0} \mathrm{~K}_{3}$ & 39.61 & 10.34 & 13.61 & 183.11 & 17.22 & 9.10 & 16.80 & 5.00 & 26.04 \\
\hline $\mathrm{C}_{1} \mathrm{~K}_{0}$ & 34.26 & 9.76 & 11.47 & 171.37 & 16.86 & 8.64 & 16.54 & 4.80 & 24.80 \\
\hline $\mathrm{C}_{1} \mathrm{~K}_{1}$ & 39.55 & 9.66 & 12.98 & 211.11 & 17.03 & 11.46 & 16.49 & 5.00 & 26.07 \\
\hline $\mathrm{C}_{1} \mathrm{~K}_{2}$ & 39.16 & 9.83 & 13.23 & 188.89 & 17.89 & 8.29 & 17.21 & 5.97 & 31.25 \\
\hline $\mathrm{C}_{1} \mathrm{~K}_{3}$ & 42.53 & 10.31 & 15.87 & 265.22 & 18.55 & 10.36 & 19.00 & 5.70 & 29.69 \\
\hline $\mathrm{C}_{2} \mathrm{~K}_{0}$ & 36.33 & 10.00 & 13.66 & 231.75 & 18.43 & 12.37 & 18.62 & 5.21 & 32.16 \\
\hline $\mathrm{C}_{2} \mathrm{~K}_{1}$ & 40.32 & 10.06 & 14.07 & 215.55 & 19.14 & 12.51 & 22.95 & 6.00 & 28.36 \\
\hline $\mathrm{C}_{2} \mathrm{~K}_{2}$ & 40.22 & 10.22 & 14.52 & 260.00 & 18.22 & 12.47 & 23.82 & 7.00 & 36.46 \\
\hline $\mathrm{C}_{2} \mathrm{~K}_{3}$ & 44.65 & 12.11 & 20.18 & 328.66 & 21.28 & 15.19 & 32.75 & 7.86 & 39.58 \\
\hline $\operatorname{LSD}_{(0.05)}$ & 0.292 & 0.182 & 0.191 & 0.295 & 3.144 & 0.266 & 0.278 & 0.062 & 0.423 \\
\hline $\operatorname{LSD}_{(0.01)}$ & 0.390 & 0.244 & 0.255 & 0.395 & 4.207 & 0.355 & 0.372 & 0.083 & 0.566 \\
\hline $\begin{array}{l}\text { Level of } \\
\text { significance }\end{array}$ & ** & $\star \star *$ & $\star \star *$ & ** & $\star \star *$ & ** & ** & ** & 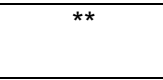 \\
\hline
\end{tabular}

( ${ }^{*}=$ Significant at $1 \%$ level of probability, DAT $=$ Days after transplanting, $\mathrm{C}_{0}=0 \mathrm{t}$ cowdung/ha, $\mathrm{C}_{1}=20 \mathrm{t} \mathrm{cowdung} / \mathrm{ha}$, $\mathrm{C}_{2}=40 \mathrm{t}$ cowdung $/ \mathrm{ha}, \mathrm{K}_{0}=0 \mathrm{~kg}$ potash $/ \mathrm{ha}, \mathrm{K}_{1}=20 \mathrm{~kg}$ potash $/ \mathrm{ha}, \mathrm{K}_{2}=50 \mathrm{~kg}$ potash $/ \mathrm{ha}, \mathrm{K}_{3}=80 \mathrm{~kg}$ potash $/ \mathrm{ha}$ )

\section{References}

Azad, A.K. 2000. Effect of plant spacing, sources of nutrients and mulching on growth and yield of cabbage. M. S. Thesis Department of Horticulture., Bangladesh Agricultural University, Mymensingh. pp. 15-40.

BBS (Bangladesh Bureau of Statistics). 2010. Statistical Yearbook of Bangladesh. Bangladesh Bur. of Stat., Stat. Div. Minis. Plan. Govt. People's repub. Bangladesh. p.134.

Busayong, E.A. 1996. Comparative analysis on the effects of compost and inorganic fertilizers on the growth, yield and pest damage on cabbage incorporated with tomatoes. Philippines J. Crop Sci., 9 (1). 55-60.

Chandra, G. 1989. Nutrient management. Fundamentals of Agronomy, Oxford and IBH Publishing Co. New Delhi, India. I. c. 156.

Farooque, A.M. and Mondal, M.F. 1987. Effect of spacing and levels of nitrogen on growth and yield of cabbage. Bangladesh Hort., 15 (2): 1-6.

Fischer, J. 1992. The influence of different nitrogen and potassium fertilization on the chemical flavour composition of kohlrabi (Brassica oleracea var. gongylodes L.). J. Sci. Food and Agric., 64(4):2752. 
Gianquinto, G. and Borin, M. 1995. Yield response of crisphead lettuce and kohlrabi to mineral and organic fertilization in different soils. Adv. Hort. Sci., 9(4): 193-179.

Gomez, K.A. and Goemez, A.A. 1984. Statistical Procedure for Agricultural Research. Second Edition. A Wiley Int. Science Publication, John Wiley and Sons, New York. 680 p.

Haque, E. 1985. Olkapi. Fal-Shabjir chash and pusti parichiti. Depertment of Agricultural Extension. Khamarbari, Krishikhamar Road. Dhaka-1215. pp. 12-25.

Haque, M.O. 2000. Effect of different fertilizer management practices on the growth and yield of main and ratoon crop of cabbage. An MS Thesis, Department of Horticulture., Bangladesh Agricultural University, Mymensingh. 96 p.

Kabir, H.T. 1998. Effect of sources of nutrient on yield and quality of cabbage. MS Thesis, Depatment of Horticulture, Bangladesh Agril. Univ., Mymensingh. pp. 13-39.

Lawande, K.E., Patil, J.D., Bhore, D.P. and Khaire, V. 1988. Response of knolkhol to nitrogen, phosphorus and potassium fertilization. J. Maharashtra Agril. Univ., 13 (3):266-267.

Nieuwhof, M. 1996. Cole Crops. Leonard Hill Books, London. 353 p.

Roe, N. 1998. Analysing results on lawns and farm crops. Biocycle, 39 (20): 62-63. [Cited from Hort. Abst., 68 (8): 3927 ].

Subhan, M. 1988. Effect of organic materials on growth and production of cabbage (Brassica oleracea L.). Bull. Prepetition Hort., 16(4): 37-41[Cited from Hort. Abst. 61(3):1937, 1990].

UNDP and FAO. 1988. Land Resources Appraisal of Bangladesh for Agricultural Development. Report No. 2. Agroecological Regions of Bangladesh. Food and Agriculture Organigation of the United Nations, Rome, Italy. pp. 212-221. 